\title{
Factors affecting the quality of external auditing services
}

\author{
Fedaa Abd Almajid Sabbar ALARAJI \\ Craiova University, Craiova, Romania \\ fdaasabbar@yahoo.com
}

Zaid Yaseen Saud AL-DULAIMI

The Bucharest University of Economic Studies, Bucharest, Romania

zaidyaseen610@yahoo.com

\author{
Thamer Mahdi Muhamed SABRI \\ Ministry of Higher Education, Iraq \\ Nabeelmahdi100@gmail.com \\ Elena Iuliana ION \\ Craiova University, Craiova, Romania \\ ion_elena_iuliana@yahoo.com
}

\begin{abstract}
This study is aim to adopt knowledge the specific concept to external audit quality and which are the factors that affecting on those qualities in the State of Iraq. As well as, to knowledge the range of depend this job in Iraq on international or local criterion to external audit quality or not. Also, to identify the satisfaction of interested parties about job of audit on service of external audit or not. According to viewpoint external audit the workers in this job and interested parties about external audit in Iraq where practice the profession of external audit under the supervision and control of the board of the profession consists of members appointed by the government ministries no are elected. The study reached to a set of many conclusions, most important of all that the realization external audit in Iraq for importance of external audit quality. Although no existence no concept of specific criterion for quality, whether international or local. Therefore, this study recommends a set of recommendations necessary to adopt uniform criterion for the quality of the external audit job in Iraq, whether international or local, to achieve high quality in audit services and achieving satisfaction of interested parties on those services.
\end{abstract}

Keywords: external audit, quality, auditor, companies, control

\section{Introduction}

External audit quality and quality criteria and the factors that effect for it, and methods of its improving consider of importance topic which studies by many academic researchers and professional organizations. It is seek to development the job of external audit and restoration the trust to the interested parties and beneficiary from service external audit after the retreat of trust in the credibility of services for this job on account of collapses and financial failure of many international companies. Despite, the submission its financial data for auditing by largest offices external audit global, without recorded any notes or forecasting of the collapses and financial failures in the future for those companies in report the office of external audit which its audit (Ayad,2005). Therefore, an importance the job of external audit in the State of Iraq as one of the developing countries where those countries have privacy in the management of this job. By boards of supervision and control of 
government, this study is try to development the efforts made in previous studies to knowledge of concept external audit quality and criterion those quality, and effective factors for quality, and methods its improving and control on its in the State of Iraq.

\section{The study methodology Study aim}

This study aim on identify on exciting specific concepts for external audit quality in general form and in Iraq private form. And what is criterion of external audit quality supported in Iraq? As well as to identify on effective factors which effect on those qualities. And which are the methods that improving and range the satisfaction of interested parties about service of external audit in Iraq.

\section{Study hypotheses}

Hypothesis of study, as follows:

- There are significant differences between the parties interested in the process of external audit and the concept of external auditing quality.

- There are no significant differences between the parties interested in the process of external audit and there is no agreement found between these parties and the relative importance of each factor from factors affecting the external auditing quality.

- There are no significant differences between the parties interested in the process of external audit and the methods for improving the external auditing quality.

\section{Theoretical frame for the study Previous studies}

The researcher will present the most important previous studies and its findings of and determine the current study site it :

Auditors are expected to be objective at all times in the course of their duties.

The independence of an auditor guarantees objectivity and imposes trust and confidence in the users of the financial statements. Chia-Ah and Karlsson (2010), states that independence can be of two forms; independence of mind and independence in appearance. De Angelo (1981), has theoretically analyzed the relationship between audit quality and auditor's size. Ebrahim (2001), observes that De Angelo (1981), argues that large auditors will have more clients and their total fees will be allocated among those clients. Ebrahim (2001), states that the results of some empirical papers have provided additional support for the use of auditor size as a proxy for audit quality.

About the current study they are trying to identify a specific concept for the external audit quality and agreement on this concept. And what is supported criterion for quality? As well as to identify on effective factors which effect on those qualities And which are the methods that improving and range the satisfaction of interested parties about service of external audit in Iraq.

\section{The concept of external auditing quality}

About the concept of external auditing quality: varied of opinion and definitions around it and that this diversity and variation caused by the multiplicity of interested parties in the job of external auditing and differences in the assessment of external auditing quality. 
Knapp shows external auditing quality to be the range of ability auditor on discovery of errors and cheating and manipulation during the implementation of the external auditing process (Knapp, 1991). Grant shows the external auditing quality to be the probability of doing the office of external auditing to discover the error from financial statements and report it (Grant et al., 1996). Ahmed shows that the external auditing quality means commitment to the professional criteria for auditing and the rules and ethics of professional conduct and guidelines for audit, as well as the rules and procedures issued by professional bodies to regulate the profession and the integrity of the external audit by the external auditor (Ahmed, 1999). Krihnan and Schaure do their research on measured external auditing quality by range of commitment by measured external audit (Krishnan \& Schaure, 1999). Hassanien and Kotb show external auditing quality is to ensure doing auditor work in order to achieve the parties of relevant (users of financial statements and the offices of audit and professional organizations, government agencies and the place of company audit) The expected aims of the auditing process (Hassanien \& Kotb, 2003).

\section{The factors affecting the external auditing quality}

The current paper proposes a set of effective factors on the external audit quality, taking into consideration, viewpoints from each party involved in the job of external auditing. This frame consists of three sets:

- The first set: the factors affecting the external auditing quality which are linked by political, economic and social environment.

- The second set: the factors affecting the external auditing quality which are linked by the regulatory environment for the profession of external audit.

- The third set: the factors affecting the external auditing quality which are linked by the regulatory environment for the office of the external auditor.

About Third set: affecting factors on external auditing quality linked the regulatory environment for the Office of External Audit:

- The size of the office of external audit: some see there is a positive relationship between the size of the office and the external auditing quality (Hassanein \& Kotp, 2003), where increasing external auditing quality the larger the size of the office, which is the process of Audit.

- The reputation of the external auditing office: some studies reached the conclusion of the existence of a positive relationship between the reputation of the external audit office and auditing quality (AL Tuwaijri \& AL Nafabi, 2008).

- Commitment to the generally accepted professional criterion: the external quality requirement is committed to the professional criterion for external quality by the rules of professional behavior during all stages of the auditing process (Gibran, 2010).

- Fees the process of external auditing: studies show that the increased effort of auditing leads to the estrangement of the auditors from the profession and increased value of competition in large offices to its bigger effect on small offices (AL Shtri \& AL Angari, 2006).

- Independence of the external auditor: the lack of independence of the external auditor is one of main the reasons of the failed auditing process.

- Experience of auditing team: studies confirm increased experience of the auditing team common in the auditing process leads to increased external auditing quality. 
- Company size: if the company was large about its business, there is a separation between owners and management that will increase the cost of the agency, thus, increasing the needs for an auditing service which has high quality (AL Dhraoei, 2002).

- The structure of external auditing: is considered important determining factors influencing external auditing quality.

\section{The methods for improving the process of external auditing quality}

There are much of the studies and professional practices by professional organizations proposed work on a set of methods, which are object to improving the external auditing quality as follows:

- Scientific and practical development and qualification for the external auditor.

- Placing criteria for controlling external auditing quality.

- Putting methods of control on the external auditing quality, including: peer review and style of the Supervisory Board on the offices of external auditing.

- Supporting the independence of external auditing through the formation of the Audit Committee or the mandatory change for external auditor.

\section{The methodology of field study}

Studies were used to answer the following questions:

- Are there significant differences for the concept of external auditing quality between the interested parties in the process of external audit?

- Are there significant differences regarding the factors affecting the external auditing quality between the interested parties in the process of external audit?

- Are there significant differences regarding the methods of improving the external auditing quality between the interested parties in the process of external audit?

\section{Community and sample study}

We determined the study population as follows:

Offices of the external audit in Iraq which are based on the process of external audit and financial managers in Iraqi contribution companies to be audited as well as credit managers in Iraqi private banks as beneficiary parties from the quality of the external auditing service and.

After reviewing the data backed in the questionnaire and unloading it in electronic tables and its treatment by electronic computer we analyzed it statistically by using a program (spss). We used the following statistical methods (Tofek, 1983):

- Some descriptive statistics such as percentages and averages.

- Test (Ka) to test to show the significant difference between the opinions of interested parties in the process of external audit.

- Test kruskal wallis test to show the significant difference between interested parties by process of the external audit.

Analyzing the results of the field study:

Table 1. Personal properties for respondent of relating them to the academic qualification Distribution of the study sample according to academic qualification

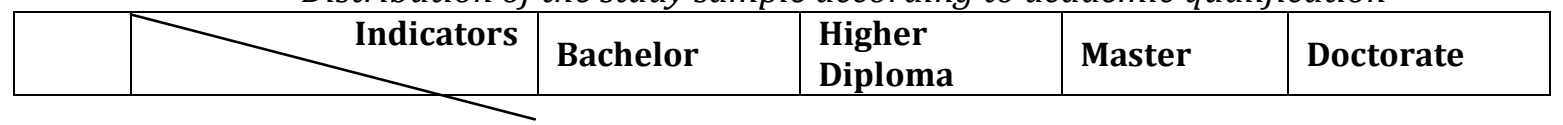

DOI: 10.1515/picbe-2017-0060, pp. 557-568, ISSN 2558-9652| Proceedings of the $11^{\text {th }}$ International Conference on Business Excellence 


\begin{tabular}{|l|l|l|l|l|l|}
\hline & Parties & & & & \\
\hline 1 & External Auditors & $82.3 \%$ & $4.7 \%$ & $2.4 \%$ & $10.6 \%$ \\
\hline 2 & External Auditors & $84 \%$ & $8 \%$ & $8 \%$ & $0 \%$ \\
\hline 3 & External Auditors & $85.2 \%$ & $0 \%$ & $14.8 \%$ & $0 \%$ \\
\hline
\end{tabular}

Source: Statistical analysis of the data field study.

The test for this hypothesis depended on the first question, which included three concepts for the external auditing quality in the first section of questionnaire in Table 2 .

Table 2. A significant difference regarding the concept of external auditing quality Test (Ka)

\begin{tabular}{|c|c|c|c|c|c|c|c|}
\hline & \begin{tabular}{|l|} 
Concepts of \\
external \\
auditing quality
\end{tabular} & $\begin{array}{l}\text { External } \\
\text { Auditors } \\
\%\end{array}$ & $\begin{array}{l}\text { Managers of } \\
\text { finance } \\
\text { companies \% }\end{array}$ & \begin{tabular}{|l|} 
Managers \\
of credit \\
Banks \%
\end{tabular} & KA & $\begin{array}{l}\text { Significance } \\
\text { level }\end{array}$ & $\begin{array}{l}\text { Variation } \\
\text { type }\end{array}$ \\
\hline 1 & $\begin{array}{l}\text { Discover and } \\
\text { Reporting of } \\
\text { Error }\end{array}$ & 10.6 & 23 & 3.7 & 8.698 & 0.013 & Significant \\
\hline 2 & $\begin{array}{l}\text { Commitment to } \\
\text { the professional } \\
\text { criterion }\end{array}$ & 60 & 27 & 37 & 20.863 & 0.000 & Significant \\
\hline 3 & \begin{tabular}{|l|} 
To satisfy the \\
desires and \\
achieve \\
satisfaction of the \\
interested \\
parties in the \\
external auditing \\
process \\
\end{tabular} & 29.4 & 50 & 59.3 & 11.319 & 0.003 & Significant \\
\hline
\end{tabular}

Source: Statistical analysis of the data field study.

If the level of significance is less than (0.05) it means that significant differences were found, and the other way around.

Table 2. found significant differences in the opinions of interested parties in the profession of external audit in Iraq. And thus we accept the first hypothesis about the existence of significant differences between the interested parties in the profession of external audit around the concept of external auditing quality.

This difference in the opinions of parties interested in the profession of external audit in Iraq regarding the concept of external auditing quality is compatible with what came from the theoretical and practical accounting and audit literature about the concept of external auditing quality considering all parties involved in the process of external audit differently.

Testing the second hypothesis: In the test, this hypothesis depends on the factors which were mentioned in the second section of the questionnaire as in Tables 3 and 4: 
Table 3. A significant difference over the factors affecting the quality of the external audit (Test Kruskal- Wallis)

\begin{tabular}{|c|c|c|c|c|c|c|c|c|c|c|c|c|c|c|c|c|}
\hline \multirow{3}{*}{ 密 } & \multirow[b]{2}{*}{ Factor name } & \multicolumn{4}{|c|}{ External Auditors \% } & \multicolumn{4}{|c|}{$\begin{array}{l}\text { Corporate finance } \\
\text { managers } \%\end{array}$} & \multicolumn{4}{|c|}{$\begin{array}{c}\text { Banks and credit } \\
\text { managers } \%\end{array}$} & \multirow{2}{*}{ 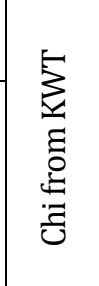 } & \multirow{2}{*}{ 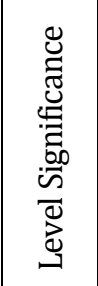 } & \multirow{2}{*}{ 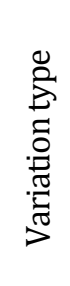 } \\
\hline & & 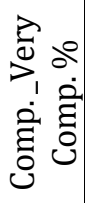 & 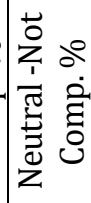 & 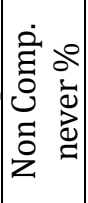 & 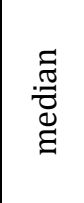 & 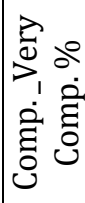 & 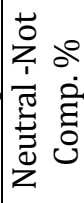 & 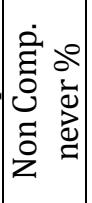 & : & 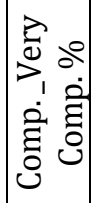 & 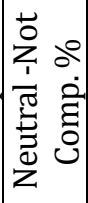 & $\mid \begin{array}{cc}\dot{c} & 0 \\
0 & 0 \\
0 & 0 \\
0 & 0 \\
0 & 0 \\
z & \vdots\end{array}$ & : & & & \\
\hline & \multicolumn{16}{|c|}{ Factors relating to the external audit office } \\
\hline 1 & $\begin{array}{l}\text { Size of the external } \\
\text { audit office }\end{array}$ & 68.2 & 11.8 & 20 & 3.67 & 61 & 18 & 21 & 3.53 & 70.4 & 11.1 & 18.5 & 3.67 & 0.613 & 0.736 & $\begin{array}{l}\text { Not } \\
\text { sign. }\end{array}$ \\
\hline 2 & $\begin{array}{l}\text { A reputable } \\
\text { professional to the } \\
\text { Office of External } \\
\text { Audit }\end{array}$ & 93 & 3.5 & 3.5 & 4.41 & 88 & 9 & 3 & 4.42 & 100 & .. & .. & 4.59 & 0.802 & 0.670 & $\begin{array}{l}\text { Not } \\
\text { sign. }\end{array}$ \\
\hline 3 & $\begin{array}{l}\text { Lawsuits against } \\
\text { the external audit } \\
\text { office }\end{array}$ & 83.6 & 8.2 & 8.2 & 4.04 & 69 & 16 & 15 & 3.79 & 59.3 & 14.8 & 25.9 & 3.41 & 3.975 & 0.137 & $\begin{array}{l}\text { Not } \\
\text { sign. }\end{array}$ \\
\hline 4 & $\begin{array}{l}\text { Competition } \\
\text { between external } \\
\text { audit firms }\end{array}$ & 84.7 & 8.2 & 7.1 & 4.05 & 76 & 12 & 12 & 3.83 & 70.4 & 18.5 & 11.1 & 3.89 & 1.765 & 0.414 & $\begin{array}{l}\text { Not } \\
\text { sign. }\end{array}$ \\
\hline 5 & $\begin{array}{l}\text { Allocate the } \\
\text { external audit firms }\end{array}$ & 75.3 & 12.9 & 11.8 & 3.86 & 63 & 12 & 25 & 3.60 & 70.4 & 7.4 & 22.2 & 3.89 & 2.737 & 0.254 & $\begin{array}{l}\text { Not } \\
\text { sign. }\end{array}$ \\
\hline 6 & $\begin{array}{l}\text { Commitment } \\
\text { external audit } \\
\text { standards }\end{array}$ & 98.8 & .. & 1.2 & 4.66 & 98 & 1 & 1 & 4.67 & 92.6 & 7.4 & .. & 4.48 & 2.459 & 0.292 & $\begin{array}{l}\text { Not } \\
\text { sign. }\end{array}$ \\
\hline 7 & $\begin{array}{l}\text { Commitment } \\
\text { quality control } \\
\text { standards }\end{array}$ & 100 & .. & .. & 4.66 & 95 & 3 & 2 & 4.52 & 92.6 & 7.4 & .. & 4.52 & 1.601 & 0.449 & $\begin{array}{l}\text { Not } \\
\text { sign. }\end{array}$ \\
\hline 8 & $\begin{array}{l}\text { The length of the } \\
\text { correlation } \\
\text { external audit } \\
\text { office }\end{array}$ & 80 & 10.6 & 9.4 & 3.95 & 71 & 12 & 17 & 3.83 & 58.2 & 3.7 & 11.1 & 4.11 & 2.370 & 0.306 & $\begin{array}{l}\text { Not } \\
\text { sign. }\end{array}$ \\
\hline 9 & $\begin{array}{l}\text { The size of the } \\
\text { external auditor } \\
\text { wages }\end{array}$ & 70.6 & 17.6 & 11.8 & 3.79 & 63 & 14 & 23 & 3.57 & 63 & 18.5 & 18.5 & 3.70 & 0.917 & 0.632 & $\begin{array}{l}\text { Not } \\
\text { sign. }\end{array}$ \\
\hline 10 & \begin{tabular}{|l|} 
Followers of \\
structured audit \\
approach
\end{tabular} & 92.9 & 4.7 & 2.4 & 4.15 & 81 & 17 & 2 & 3.99 & 74.1 & 18.5 & 7.4 & 3.81 & 5.453 & 0.065 & $\begin{array}{l}\text { Not } \\
\text { sign. }\end{array}$ \\
\hline \multicolumn{17}{|c|}{ Secondly Factors related to team work of the external auditor } \\
\hline 11 & $\begin{array}{l}\text { External audit } \\
\text { team experience }\end{array}$ & 97.7 & 1.2 & 1.1 & 4.64 & 98 & 2 & .. & 4.63 & 100 & .. & 97.7 & 1.2 & 1.1 & 4.64 & 98 \\
\hline 12 & $\begin{array}{l}\text { New connections } \\
\text { between Team } \\
\text { Audit and the } \\
\text { audit client }\end{array}$ & 83.5 & 9.4 & 7.1 & 3.99 & 80 & 9 & 11 & 4.05 & 85.2 & 7.4 & 83.5 & 9.4 & 7.1 & 3.99 & 80 \\
\hline 13 & $\begin{array}{l}\text { Company size } \\
\text { replace the audit } \\
\text { External }\end{array}$ & 58.8 & 24.7 & 16.5 & 3.60 & 59 & 21 & 20 & 3.49 & 51.8 & 14.8 & 33.4 & 58.8 & 24.7 & 16.5 & 3.60 \\
\hline
\end{tabular}




\begin{tabular}{|c|c|c|c|c|c|c|c|c|c|c|c|c|c|c|c|}
\hline $14 \begin{array}{l}\begin{array}{l}\text { Internal control of } \\
\text { the company } \\
\text { structure replace } \\
\text { the external audit }\end{array} \\
\end{array}$ & 89.4 & 8.2 & 2.4 & 4.42 & 92 & 6 & 2 & 4.43 & 81.5 & 7.4 & 11.1 & 89.4 & 8.2 & 2.4 & 4.42 \\
\hline $15 \begin{array}{l}\text { The complexity of } \\
\text { the external audit } \\
\text { functions }\end{array}$ & 67 & 22.4 & 10.6 & 3.69 & 55 & 30 & 15 & 3.53 & 70.4 & 7.4 & 22.2 & 67 & 22.4 & 10.6 & 3.69 \\
\hline
\end{tabular}

Source: Statistical analysis of the data field study.

PICBE | 563

Table 4. The relative importance of the factors affecting the quality of the external audit)

\begin{tabular}{|c|c|c|c|c|c|c|c|c|c|}
\hline & \multirow[b]{2}{*}{ Factor name } & \multicolumn{2}{|c|}{$\begin{array}{l}\text { External } \\
\text { Auditors }\end{array}$} & \multicolumn{2}{|c|}{$\begin{array}{l}\text { Corporate finance } \\
\text { managers }\end{array}$} & \multicolumn{2}{|c|}{$\begin{array}{l}\text { Banks and credit } \\
\text { managers }\end{array}$} & \multirow{2}{*}{ 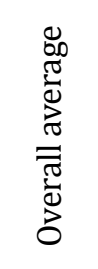 } & \multirow{2}{*}{ 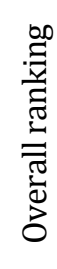 } \\
\hline & & 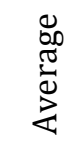 & 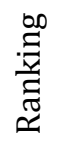 & 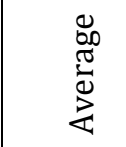 & 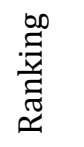 & 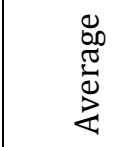 & 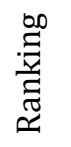 & & \\
\hline 1 & $\begin{array}{l}\text { The size of the external audit } \\
\text { office }\end{array}$ & 3.67 & 13 & 3.53 & 12 & 3.67 & 11 & 3.60 & 14 \\
\hline 2 & $\begin{array}{l}\text { A reputable professional to office } \\
\text { audit }\end{array}$ & 4.41 & 4 & 4.42 & 5 & 4.459 & 2 & 4.44 & 4 \\
\hline 3 & $\begin{array}{l}\text { Lawsuits against the external } \\
\text { audit office }\end{array}$ & 4.04 & 7 & 3.79 & 9 & 3.41 & 12 & 3.84 & 10 \\
\hline 4 & $\begin{array}{l}\text { Competition between external } \\
\text { audit firms }\end{array}$ & 4.05 & 6 & 3.83 & 8 & 3.89 & 8 & 3.924 & 8 \\
\hline 5 & Allocate the external audit firms & 3.86 & 10 & 3.60 & 10 & 3.89 & 8 & 3.74 & 11 \\
\hline 6 & $\begin{array}{l}\text { Commitment external audit } \\
\text { standards }\end{array}$ & 4.66 & 1 & 4.67 & 1 & 4.48 & 4 & 4.64 & 2 \\
\hline 7 & $\begin{array}{l}\text { Commitment quality control } \\
\text { standards }\end{array}$ & 4.66 & 1 & 4.52 & 3 & 4.52 & 3 & 4.58 & 3 \\
\hline 8 & $\begin{array}{l}\text { The length of the correlation } \\
\text { external audit office }\end{array}$ & 3.95 & 9 & 3.83 & 8 & 4.11 & 7 & 3.915 & 9 \\
\hline 9 & $\begin{array}{l}\text { The size of the external auditor } \\
\text { wages }\end{array}$ & 3.79 & 11 & 3.57 & 11 & 3.70 & 10 & 3.67 & 12 \\
\hline 10 & $\begin{array}{l}\text { Followers structural audit } \\
\text { method }\end{array}$ & 4.15 & 5 & 3.99 & 7 & 3.81 & 9 & 4.03 & 7 \\
\hline 11 & External audit team experience & 4.64 & 2 & 4.63 & 2 & 4.81 & 1 & 4.66 & 1 \\
\hline 12 & $\begin{array}{l}\text { New communication between the } \\
\text { external audit team and the client } \\
\text { external audit }\end{array}$ & 3.99 & 8 & 4.05 & 6 & 4.22 & 5 & 4.05 & 6 \\
\hline 13 & $\begin{array}{l}\text { Size of the company replace the } \\
\text { external audit }\end{array}$ & 3.60 & 14 & 3.49 & 13 & 3.22 & 13 & 3.50 & 15 \\
\hline 14 & $\begin{array}{l}\text { Internal control of the company } \\
\text { structure replaces the external } \\
\text { audit }\end{array}$ & 4.42 & 3 & 4.43 & 4 & 4.19 & 6 & 4.40 & 5 \\
\hline 15 & $\begin{array}{l}\text { The complexity of the external } \\
\text { audit functions }\end{array}$ & 3.9 & 12 & 3.53 & 12 & 3.67 & 11 & 3.61 & 13 \\
\hline
\end{tabular}

Source: Statistical analysis of the data field study.

As shown in tables 3. and 4., there is no significant difference in the opinions of interested parties in the process of external audit about the factors affecting the profession of external auditing quality as support for all the profession parties on the influence of all the factors contained in the study on the profession of external auditing in Iraq and as shown in table 3 . These parties differ in their opinions on the relative importance of each 
factor from the factors affecting the quality of the external audit so as a result, we accept the second hypothesis.

Testing the third hypothesis: In testing this hypothesis we depended on the answer of interested parties in the profession of external audit in the third section of the questionnaire, as shown in Table 5:

Table 5. Table variations on ways to improve the quality of external audit (Kruskal-Wallis test)

\begin{tabular}{|c|c|c|c|c|c|c|c|c|c|c|c|c|c|c|c|c|}
\hline \multirow{3}{*}{ 窇 } & \multirow[b]{2}{*}{ Factor name } & \multicolumn{4}{|c|}{ External Auditors \% } & \multicolumn{4}{|c|}{$\begin{array}{c}\text { Corporate finance } \\
\text { managers } \%\end{array}$} & \multicolumn{4}{|c|}{$\begin{array}{c}\text { Banks and credit } \\
\text { managers } \%\end{array}$} & \multirow{2}{*}{ 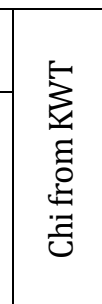 } & \multirow{2}{*}{ 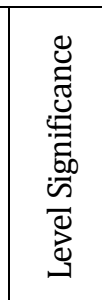 } & \multirow[b]{2}{*}{ 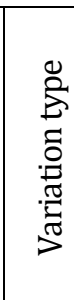 } \\
\hline & & $\begin{array}{ll}2 & \\
0 & 0 \\
> & 1 \\
\dot{2} & \vdots \\
\vdots & 0 \\
0 & 0\end{array}$ & 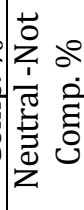 & 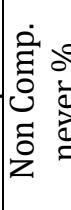 & : & $\begin{array}{ll}2 & \\
0 & 0 \\
D_{1} & 0 \\
\dot{2} & \vdots \\
\vdots & 0 \\
0 & 0\end{array}$ & 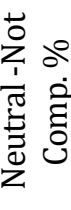 & 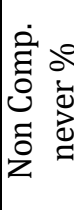 & $\frac{\pi}{\overparen{Z}}$ & 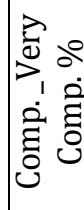 & 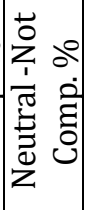 & 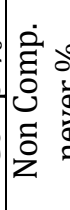 & 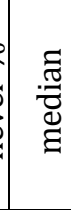 & & & \\
\hline & \multicolumn{16}{|c|}{ Ways of improving the quality of external audit } \\
\hline 1 & $\begin{array}{l}\text { The existence of } \\
\text { standards for } \\
\text { controlling the } \\
\text { quality of the } \\
\text { external audit }\end{array}$ & 97.7 & $\ldots$ & 2.3 & 4.61 & 99 & $\ldots$ & 1 & 4.61 & 100 & $\ldots$ & $\ldots$ & 4.81 & 3.272 & 0.195 & $\begin{array}{l}\text { Not } \\
\text { sign. }\end{array}$ \\
\hline 2 & $\begin{array}{l}\text { Quality control of } \\
\text { external audit by } \\
\text { the peer auditing }\end{array}$ & 69.4 & 17.6 & 13 & 3.8 & 52 & 19 & 29 & 3.3 & 66.7 & 18.5 & 14.8 & 3.67 & 7.188 & 0.027 & $\begin{array}{l}\text { Not } \\
\text { sign. }\end{array}$ \\
\hline 3 & $\begin{array}{l}\text { Quality control of } \\
\text { external audit by } \\
\text { a government } \\
\text { body }\end{array}$ & 29.4 & 15.3 & 55.3 & 2.66 & 43 & 27 & 30 & 3.22 & 37 & 29.6 & 33.4 & 3.11 & 10.26 & 0.006 & $\begin{array}{l}\text { Not } \\
\text { sign. }\end{array}$ \\
\hline 4 & $\begin{array}{l}\text { Strengthening the } \\
\text { independence of } \\
\text { the external } \\
\text { auditor }\end{array}$ & 94 & 1.2 & 4.8 & 4.45 & 98 & 1 & 1 & 4.51 & 92.6 & 3.7 & 3.7 & 4.56 & 50.821 & 0.663 & $\begin{array}{l}\text { Not } \\
\text { sign. }\end{array}$ \\
\hline 5 & $\begin{array}{l}\text { Requirement for } \\
\text { the external audit } \\
\text { firms that } \\
\text { auditors pass a } \\
\text { certain number of } \\
\text { hours of } \\
\text { continuing } \\
\text { professional } \\
\text { education }\end{array}$ & 91.8 & 7.1 & 1.1 & 4.42 & 87 & 9 & 4 & 4.25 & 88.8 & 7.4 & 3.8 & 4.33 & \begin{tabular}{l|l|l|}
3 & 2.190
\end{tabular} & 0.334 & $\begin{array}{l}\text { Not } \\
\text { sign. }\end{array}$ \\
\hline
\end{tabular}

Source: Statistical analysis of the data field study.

Table 5 notes that there are no significant differences between the opinions of interested parties in the process of external audit regarding most methods for improving the external auditing quality. Exception of the two methods means control on the external auditing quality by the peer scrutiny and control over the external auditing quality by a government body.

\section{Conclusions}

After the theoretical and field study research, we reached the following conclusions: 
- There are significant differences regarding the concept of external auditing quality between interested parties in the profession of external audit in Iraq where each party regards the external auditing quality, according to his vision and interests and this corresponds with previous studies applied in same countries have shown there is no a specific concept for the quality of the external audit.

- There are no significant differences regarding the factors affecting the profession of external auditing quality by the interested parties in the profession of external audit in Iraq, and those parties differ regarding the relative importance of each factor of the factors affecting the external auditing quality.

- There are no differences in significant methods of improving external auditing quality in Iraq by the interested parties in the profession of external audit in Iraq, with a difference between those parties regarding the means of control over the quality of the office of external audit by the government body and the council of surveillance and supervision of the profession monitoring accounts in Iraq.

\section{References}

Ahmed, A. A. A. (1999). Quality control of system external audit. PhD Dissertation. Cairo University, 157.

AL Shatri, I. H., \& AL Angri, H. (2006). The low level of external audit fees and its impact on the quality of performance. Journal of King Abdul Aziz of Administration and the Economy. 97.

AL Tuwaijri, A., \& AL Nafabi, M. (2008). Quality external audit service. Journal University of King Abdulaziz, 219.

Ayad,H.H.(20050.Factors Affecting the Quality of the external Auditing,Masters thesis, Gaza University, 14 .

Chia-Ah \& karlsson,J. (2010).The impact of extended audit tenure on audit Independence, (Unpublished Masters Thesis),Umea school of Business , Greece .

De Angelo,I, (1981), Auditor size and audit quality. Journal of Accounting and Econmics, 2(1) .

Dye,R.(1993). Auditing standards,legal liability and auditor wealth. The Journal of political Economy,10(4).

Ebrahim, A. (2001). Auditing quality, auditing tenure, client importance and earnings management. Paper presented at Rutgers Univversity.

Eldahraoi, K. (2002). Methods research in field of accounting. AL Scandrie University Publishing House, 99.

Grant, J., Bicker, R., \& Shiptsova, R. (1996). Audit quality and professional self-regulation: A social dilemma perspective and laboratory investigation Auditing. A Journal of Practice and Theory, 15(1), 142.

Hassanein, T. M., \& Kotb, A. (2003). Analytical study of the factors and models of measure quality external audit. Journal of Accounting and Management and Insurance. College of Business-Cairo-University, 355.

Knapp, C. M. (1991). Factors, that audit committee quality. Auditing, Journal of Practice and Theory, 10(1), 38.

Krishan, J., Schaure, P. C. (1999). The differentiation of quality among auditors. Journal of Practice and Theory, 21. 
Mohammed, G. A. (2010). Factors affecting the quality of the external audit. College of Business Administration University of King Saud, 39.

Tofek, A. (1983). The statistical analysis in the educational psychological and social research. Kuwait, 201.

PICBE $\mid 566$ 


\section{Appendix \\ Questionnaire}

Q1: Chose the right concept for the quality of external audit in your opinion.

\begin{tabular}{|l|l|l|}
\hline 1 & $\begin{array}{l}\text { The discovery of the material misrepresentation in the financial statements if the find it } \\
\text { and report this material mispresentation }\end{array}$ & \\
\hline 2 & $\begin{array}{l}\text { Commitment to professional standards and rules and ethics of the profession issued by } \\
\text { professional organizations }\end{array}$ & $\begin{array}{l}\text { The external auditor work in order to achieve the expected goals of all parties of the audit } \\
\text { process }\end{array}$ \\
\hline 3
\end{tabular}

Q2: Below factors affecting on quality of the external audit:

-Determine the extent of your agreement to the effect of each factor on the quality of the external audit.

-If an influential factor, what kind of impact (positive - negative)

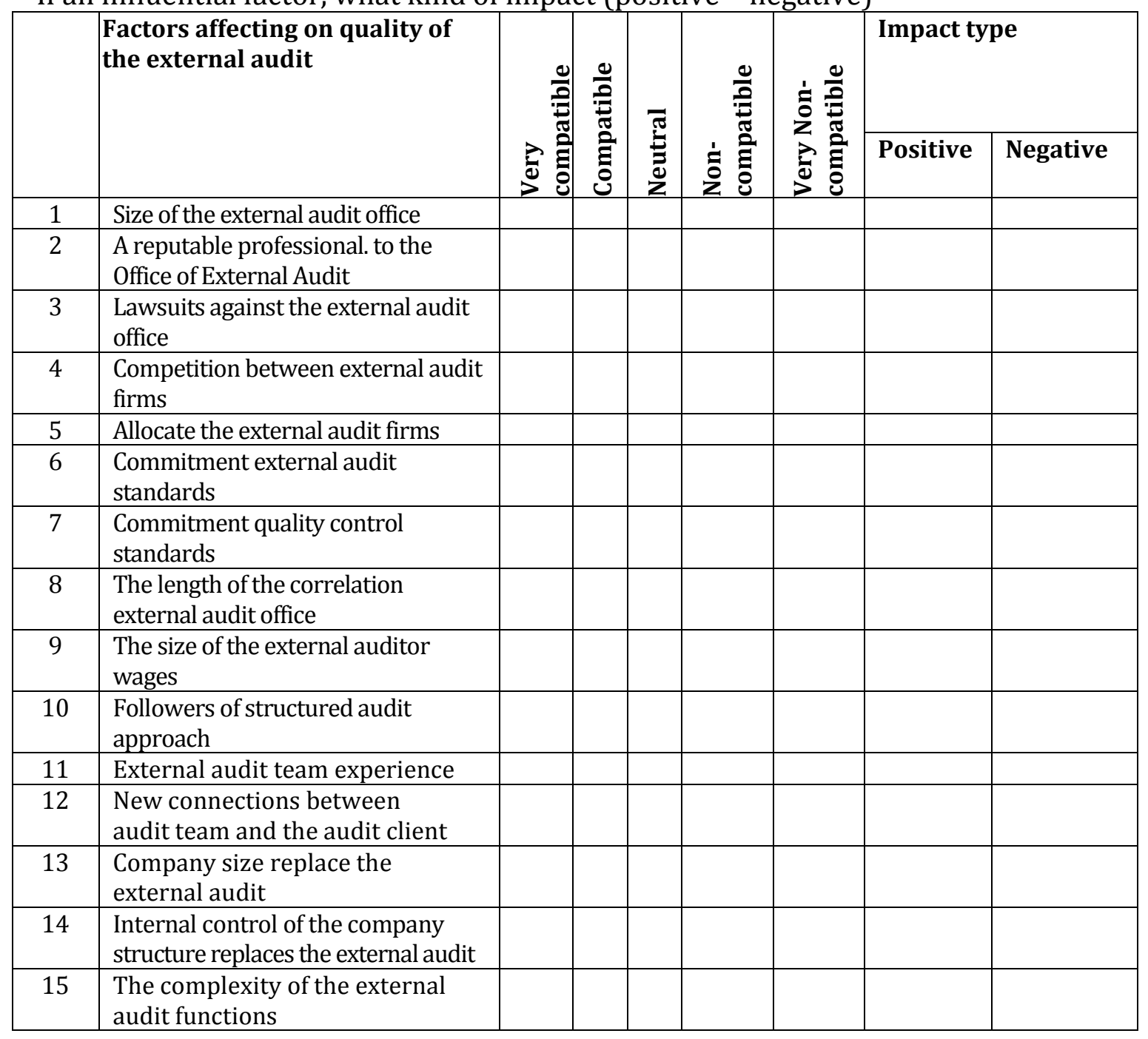


Q3: Below same ways and means to improve the quality of external audit please indicate your opinion the extent of your agreement:

\begin{tabular}{|c|l|l|l|l|l|l|}
\hline & $\begin{array}{l}\text { Tools, means, ways } \\
\text { to improve the } \\
\text { quality of external } \\
\text { audit }\end{array}$ & $\begin{array}{l}\text { Very } \\
\text { compatible }\end{array}$ & Compatible & Neutral & $\begin{array}{l}\text { Non- } \\
\text { compatible }\end{array}$ & $\begin{array}{l}\text { Very Non- } \\
\text { compatible }\end{array}$ \\
\hline 1 & $\begin{array}{l}\text { The existence of } \\
\text { standards for controlling } \\
\text { the quality of the } \\
\text { external audit }\end{array}$ & $\begin{array}{l}\text { Quality control of } \\
\text { external audit by the } \\
\text { peer auditing }\end{array}$ & & & & \\
\hline 3 & $\begin{array}{l}\text { Quality control of } \\
\text { external audit by a } \\
\text { government body }\end{array}$ & & & & \\
\hline 4 & $\begin{array}{l}\text { Strengthening the } \\
\text { independence of the } \\
\text { external auditor }\end{array}$ & & & & \\
\hline 5 & $\begin{array}{l}\text { Requirement for the } \\
\text { external audit firms that } \\
\text { auditors pass a certain } \\
\text { number of hours of } \\
\text { continuing professional } \\
\text { education }\end{array}$ & & & & & \\
\hline
\end{tabular}

PICBE | 568 